\title{
PROBLEMS OF DEVELOPING MARGINAL COASTAL SOILS IN THE WAIRARAPA
}

\section{J. G. Falloon}

"Taumaru", Longbush, M asterton

This PAPER deals in particular with the "Pukunui" property. Prior to its purchase I was involved, under the management of my brother, in the development of "Ditton", a 2,500 acre steep hill country farm 12 miles north of Masterton. Development there was relatively straightforward, the soils responding well to fertilizer, and pastures becoming reasonably good.' Carrying capacity has been raised to over 5 ewe equivalents per acre throughout the year, and further improvement can be achieved by the correction of a small amount of acidity and the application of heavier rates of phosphate.

Two years ago, I moved to "Taumaru", Longbush, where we have purchased a partially developed farm. Continued development has presented no special problems. Judicious use of molybdenum plus $1 / 2$ ton of superphosphate per acre has brought the best pastures up to 5 ewe equivalents per acre and further increases are anticipated with the correction of acidity and further application of fertilizer. Serious pugging problems in the winter and recurring summer droughts will probably be the greatest limitations to high carrying capacity.

Expert advice has been sought at all times and varies from farm advisers to a geneticist who is professionally employed as breeding adviser For our Aberdeen Angus stud herd.

All this is to indicate that, for the 22 years of my farming life, experience has been gained in the development of hill country in the Wairarapa. However, the concepts that have been formulated and applied with success at both "Ditton" and "Taumaru" have seemingly failed at "Pukunui".

"Pukunui" is 4,500 acres of steep and broken country ranging from 500 to $2,000 \mathrm{ft}$ above sea level, situated in the Wairarapa, 35 road miles from Masterton in a south-easterly direction (the homestead is $175^{\circ} 49^{\prime}$ East Long., $41^{\circ} 15^{\prime}$ South Lat.) and reaching to within a few miles of the coast. It is fairly representative of a large area of country with similar soils, stretching from the Orongorongos in the south, to Akitic in the north. 
A rainfall of about 60 in, on 120 days each year attracted us to the property at the outset. At the homestead, average annual rainfall in the period 1964 to 1968 totalled 57.31 in., distributed as follows:

$\begin{array}{llll}\text { Jan. } & 2.28 \mathrm{in.} & \text { July } & 6.48 \mathrm{in.} \\ \text { Feb. } & 2.31 \mathrm{in.} & \text { Aug. } & 8.92 \mathrm{in} . \\ \text { Mar. } & 3.81 \mathrm{in.} & \text { Sept. } & 3.86 \mathrm{in} . \\ \text { April } & 5.49 \mathrm{in.} & \text { Oct. } & 2.60 \mathrm{in} . \\ \text { May } & 5.77 \mathrm{in.} & \text { Nov. } & 2.44 \mathrm{in} . \\ \text { June } & 7.69 \mathrm{in} . & \text { Dec. } & 5.51 \mathrm{in} .\end{array}$

This is not typical for the whole farm, owing to the influence of the Taipo range formation which lies inland in the path of the prevailing winds. The higher country probably gets much more than 60 in. on some 180 to 200 days each year. In general, the rainfall is well spread and an asset to development. However, there are summer drought problems owing to topography and allied factors. Unpredictable light snowfalls cover much of the higher country two or three times from mid-autumn to midspring. On the higher slopes lying away from the sun, the surface soil may be frozen for a few days during winter. Drought effects are promoted by extensive sunny periods in summer, lack of water retention by the soil, and by the strong north-west winds which prevail. Air movement is reduced in the gully bottoms, which encourages blowfly strike in lambs. Consequently we shear our lambs in November. From time to time, violent storms sweep in off the Pacific from south and east, and deposit salt on the farm.

The first attempts at farming "Pukunui" were made about 100 years ago, when resources were limited in the extreme. Burning off was a regular policy through the property, with some oversowing with pasture seeds, but with little fertilizer. For a period prior to the last war, constant cutting kept an extensive area clear of scrub, but later, the normal conservative approach to farming, coupled with limited money and labour resources, led to extensive reversion. When we bought the property in 1957 there were 200 acres of bush, about 300 acres of solid scrub, while the remainder was scattered to semi-solid manuka (Leptospermum scoparium) on the poorer soils and tauhinu (Cassinia leptophylla) on the better soils. Azolla (Azolla rubra) covered most of the clear country. An indication of the poor pasture type is given in Table 1, which contains limited data recently obtained from undeveloped pastures. The property was defined by survey pegs, the only com- 
TABLE 1: PLUG SAMPLING OF "PUKUNUI" PASTURES, 14.10.69

A score of 100 indicates that a species was present in all plugs. Vigour of growth is not indicated directly.

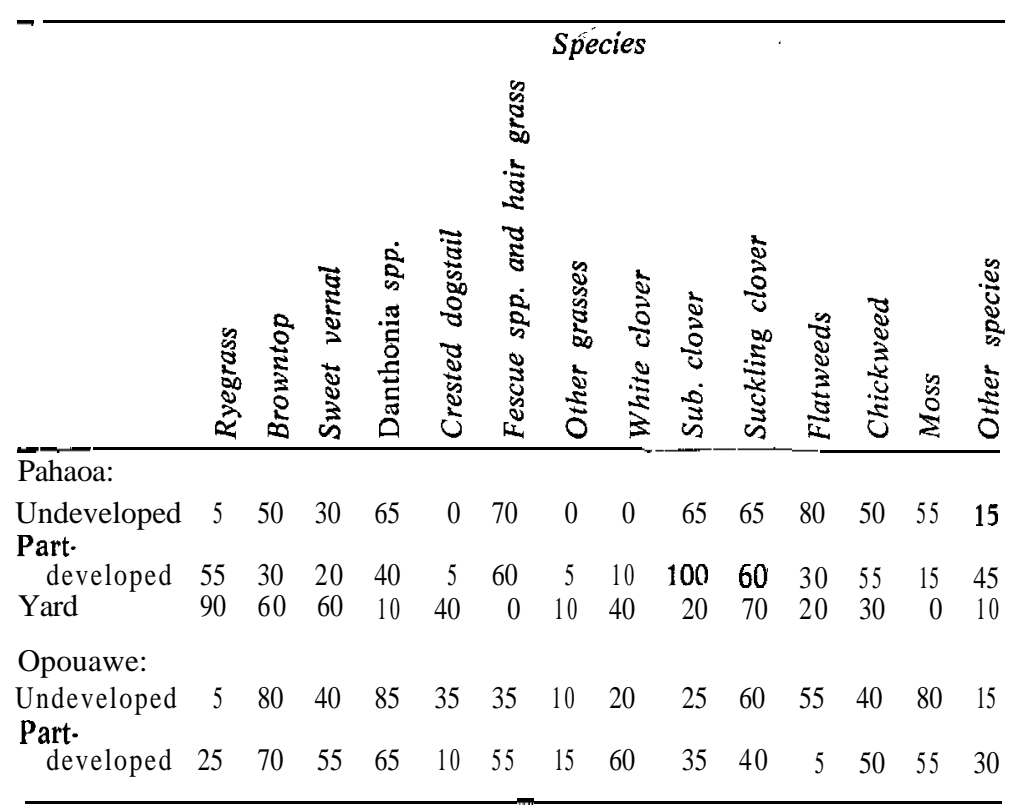

pletely fenced areas being holding paddocks and one 650 acre paddock. Small streams cut through the property, and access to most parts of the farm was on horseback, or Landrover along the 10 miles of track made prior to our purchase.

\section{BASIC CONCEPT OF DEVELOPMENT}

(1) It has always been my belief that carrying capacity in any area is controlled by climate, finance, farm management and soil type, in that order. Therefore, provided the climate is suitable, any soil can be developed with the addition of the correct nutrient.

(2) If we were to begin by cutting scrub, we would spend the rest of our lives cutting scrub - and have no finance left for development. So it was decided in the 2,500 acres of scrub to attempt to raise carrying capacity to $31 / 2$ ewes per acre and then clear the ground, in the hope that it would need only one followup "cut-over" afterwards, 
(3) We would approach development without any preconceived beliefs, and try any new ideas, no matter how revolutionary. (4) It would be treated as a whole farm development, and all areas would be grazed to the best of our ability.

\section{RESULTS}

Since 1957, we have spread 2,138 tons of superphosphate and $7,109 \mathrm{lb}$ of clover seed, all inoculated, and, for the last six years, prill-coated; cut 8 miles of tracks: constructed an airstrip; erected $181 \frac{1}{2}$ miles of new fences and completed the repair of 4 miles; built one set of cattle yards, and one set of sheep and cattle yards, etc. And for all this we have succeeded in raising the carrying capacity from 1,300 ewes to only 3,800 (4,000 in 1970), hoggets from 960 to 1,200 , breeding cows from 100 to 200 , and wool weights from $8 \mathrm{lb}$ to $9.2 \mathrm{lb} / \mathrm{ewe}$ or from $3.9 \mathrm{lb} / \mathrm{acre}$ to $10.7 \mathrm{lb} / \mathrm{acre}$. Pasture composition and vigour have improved a little (Table 1).

These results indicate that our efforts have been much less successful than we would have liked. Indeed, I could only agree, when some visiting Grasslands Division scientists questioned the wisdom of some of the decisions taken.

\section{PROBLEMS}

Many problems have been commonplace for a hill country farm. However, we have had to make full use of all methods of transport, including helicopters, to overcome distances and difficult terrain. Labour costs have been kept to a minimum by careful planning and by trying to get the most efficient animal for this environment.

The basic problem has been our inability to induce the soils to become biologically active and normal. For example, although grass grub and porina take their toll, earthworms are relatively scarce. Soil acidity is generally too high, and in places turf mats have formed. Fertile soil appears to be only 1 to 2 in. deep and ryegrass and white clover have difficulty in persisting. The soils still fail to hold water as we think they should, and summer droughts remain important.

Recently H. S. Gibbs, Soil Bureau, DSIR, made a quick survey of the soils on the property and delineated seven main types (for details see Appendix). He indicated the important effect that repeated deposits of salt have on the soil, an effect that we must live with, and drew our attention to the soils most likely to 
respond to normal fertilizer applications. This has opened up fresh possibilities.

ln plots, the Grasslands Division scientists have indicated the necessity for reducing soil acidity. However, the spreading of lime is expensive, since more than 2 tons per acre may be needed, and it moves relatively slowly down into the soil. We must decide to make use of heavy initial quantities and take full benefit of the subsidy, and then follow it with smaller repeat applications. Only economics and potential carrying capacity can supply the answer to this.

In the present condition there is a need for a vigorous pioneer plant. In last May, a 10 acre area was sown with inoculated 'Grasslands 4705' tetraploid Lotus pedunculatus to test its suitability for this purpose,

\section{THE IMPORTANCE OF SOIL TYPE}

To illustrate the importance of soil type, let us consider the best and worst two soils on the farm - Pahaoa steepland soil (Type 124b), the best, and Opouawe steepland soil (Type 120a), the worst.

\section{PahAoA STEEPLAND SoII}

By unlucky chance, the Pahaoa soil is right at the back of the farm and lying to the sun. It is naturally clear country with scattered tauhinu and considerable azolla, with traces of ryegrass. Carrying capacity was estimated at 1 ewe per acre, and is now $31 / 2$ ewes/ acre. This land has received $4 \mathrm{cwt}$ molybdic-superphosphate plus $4 \mathrm{cwt}$ superphosphate per acre, with $7 \mathrm{lb}$ white, $7 \mathrm{lb}$ Tallarook and $7 \mathrm{lb}$ Mt. Barker, subterranean clover seed per acre.

Soil quick-test data are:

\begin{tabular}{|c|c|c|c|}
\hline & $p H$ & $\mathrm{Ca}$ & $\mathrm{K}$ \\
\hline Undeveloped & 5.2 & 2 & 6 \\
\hline Partially developed & 5.3 & 5 & 10 \\
\hline Desirable levels & 5.6 & - & $s-9$ \\
\hline
\end{tabular}

In Table 1 it can be seen that ryegrass has increased dramatically with development, while moss and flatweeds have been reduced. With an increased intensity of management, this land could respond spectacularly.

Also in Table 1 are data from a small portion of the sample paddock which was enclosed 14 months previously as a yard. 
Within this short period, there has been a marked change towards the more desirable species. The yard pasture is probably equal to better-than-average North Island hill pastures even now. Earthworms are also active there and prospects are good for this soil.

\section{Opouahe Stempland Soll}

This country had a bluish grey appearance which did not change with the seasons. Vegetation consisted of manuka, azolla, browntop, danthonia, moss and little else, with big tauhinu on shady faces and in gullies.

Treatment of this soil to date has consisted' of $12 \mathrm{cwt}$ molybdic-superphosphate, $2 \mathrm{cwt}$ superphosphate and $1 / 2$ ton of lime. Eleven pounds of seed have been sown and this includes $4 \mathrm{lb}$ 'Grasslands Huia' white clover, $2 \mathrm{lb}$ Mount Barker, $2 \mathrm{lb}$ Tallarook and $3 \mathrm{lb}$ 'Grasslands Apanui' cocksfoot, all inoculated and pelleted by the DSIR. Subsequently, $20 \mathrm{lb}$ Ariki ryegrass, $2 \mathrm{lb}$ Huia white clover and $2 \mathrm{lb}$ tetraploid Lotus pedunculatus seed per acre have been sown $\mathrm{cm} 10$ acres as an experimental plot.

This country, after showing a tremendous initial response, suddenly deteriorated, with the clovers beginning to die out. There has been no copper deficiency detectable to date. Although we suspect that heavy rates of lime are required, we still do not know the answer to this soil. The Grasslands Division has trials in progress on this soil at the moment.

An estimated original carrying capacity is $1 / 2$ ewe per acre, poorly done. Estimated present carrying capacity is $31 / 2$ ewes to the acre.

Soil test data are:

$\begin{array}{lccrr} & p H & \text { Ca } & \text { K } & \text { P } \\ \text { Undeveloped soil test . . . } & 5.0 & 1 & 5 & 1 \\ \text { Partially developed . . . } & 5.2 & 6 & 6 & 5 \\ \text { Desirable } \quad \ldots \ldots & 5.6 & - & 8-9 & 7-9\end{array}$

\section{Costs}

Here is the cost of developing Opouawe steepland soil (Type $120 \mathrm{a}$ ), based upon our present limited knowledge, to raise the carrying capacity from $1 / 2$ ewe/acre to 5 ewes/acre. This soil is proving the most expensive to date, and so is taken as an example. 


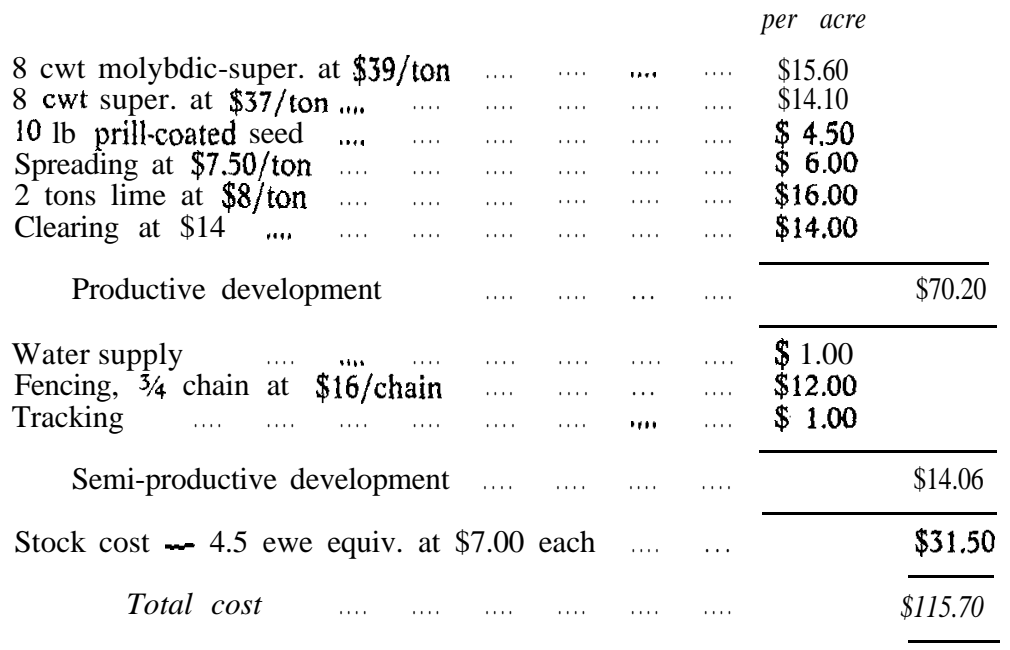

This development cost of $\$ 25.70$ per ewe equivalent is expensive and just economic.

Costing on Pahaoa steepland soil (Type 124b) developed from 1 to 5 ewe equivalents per acre:

$\begin{array}{llllllll}\text { Productive Development } & \ldots & \ldots & \ldots & \ldots & \ldots & \ldots & \$ 35.45\end{array}$

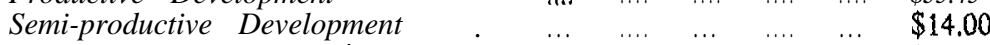

Stock cost $\rightarrow 4$ ewe equiv, at $\$ 7.00$ each $\ldots \ldots \ldots . . . . \quad \ldots \quad \$ 28.00$

$\begin{array}{lllllllllll}\text { Total } \operatorname{cost} & \ldots & \ldots & \ldots & \ldots & \ldots & \ldots & \ldots & \ldots & \ldots & \ldots\end{array}$

This development cost of $\$ 19.00$ per ewe equivalent is economic.

\section{CONCLUSIONS}

(1) State Advances Corporation current outlook for determinations of development is based upon capitalizing Gross Margins return at $10 \%$, which is made up of:

\section{$51 / 2 \%$ First mortgage interest \\ $2 \%$ Principal repayment \\ $21 / 2 \%$ Reward for management}

On the Opouawe soil the calculations show that development cost per stock unit increase is just economic, However, when taken in conjunction with the Pahaoa soils, the overall situation is favourable. 
(2) Much more research, both scientific and practical is required on the "Pukunui" type of country to understand fully how best and most cheaply to develop this type of land.

(3) Farmers interested in this type of land should have all types of soils identified and isolated.

(4) Soils must be fenced and treated individually to obtain the best results.

(5) Owing to lack of scientific research in this type of country, we have been forced to do our own. This has proved extremely costly and inefficient.

(6) If targets of the National Development Conference are to be reached, this type of land will have to be developed,

\section{APPENDIX}

\section{Other soils on "Pukunui"}

Type $25 \mathrm{aH}-$ Wanstead Hill Soil, bentonite and argillite: 80 acres approx. This is deep sticky clay soil, liable to slipping and slumping. There are no tests on this soil as it is localized. Only suitable for trees.

Type 32cH - Ngaumu hill soil, soft sandstone: 450 acres approx.

Confined in area, and little development and no soil test have been done upon it.

Type $113 \mathrm{c}-$ Toro steepland soil, calcareous argillite and sandstone: 85 acres approx.

This soil type along with the Pahaoa soils are by far the best soils. Both have reasonable quantities of plant nutrients in their undeveloped state, and respond well to topdressing, Initial carrying capacity was 1 ewe/acre.

No soil tests are available for this type in the undeveloped state, as all such areas are under development. Soil tests after the application of $16 \mathrm{cwt}$ of $44 / 46$ superphosphate and $4 \mathrm{cwt}$ of molybdic-superphosphate are:

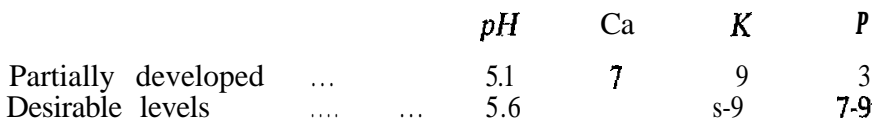

This test indicates the locking up of large quantities of phosphate by the high acidity. 
Type 119 - Whareama steepland soil, banded sandstone and siltstone: 150 acres approx.

The estimated original carrying capacity was $3 / 4$ ewe/acre, Natural vegetation manuku, azolla, browntop and moss.

$\begin{array}{llrrrrr} & & & p H & C a & \text { K } & \text { P } \\ & & & 5.0 & \mathbf{1} & 3 & 4 \\ \text { Undeveloped soil test } & & . & 5.0 & 7 & 6 & 3 \\ \text { Partially developed } & \ldots & \ldots & 5.6 & 7 & 8-9 & 7-9 \\ \text { Desirable levels } & \ldots & \ldots & 5.6 & & \end{array}$

Treatment to date $4 \mathrm{cwt}$ molybdic-superphosphate, 1 ton of $44 / 46$ superphosphate, $1 / 2$ ton of lime, $3 \mathrm{lb}$ white clover and $2 \mathrm{lb}$ subterranean clover seed per acre.

Although the pasture has the appearance of a 5 ewe/acre pasture, it never produces bulk feed, even when shut up.

\section{Type 120 - Mataikona steepland soil, argillite with some sandstone: 400 acres approx.}

The estimated carrying capacity was $3 / 4$ ewe/acre. This soil has been consistently burnt over and no development has been done to date. Vegetation is small stunted manuka and stunted azolla.

$\begin{array}{lccccrr} & & & p H & \mathbf{C a} & \text { K } & \text { P } \\ \text { Undeveloped soil } & \text { test } & & 5.1 & 4 & 7 & 1 \\ \text { Desirable levels } & \ldots & \ldots & 5.6 & & 8-9 & 7-9\end{array}$

\section{DISCUSSION}

To a question concerning rate of application of fertilizer, Falloon replied that initially it was spread over 1,000 acres at $2 \mathrm{cwt}$ per acre. $\mathrm{He}$ felt that it would probably have been more successful had he concentrated on a smaller area. The fertilizer was usually applied in December. To a suggestion by Ludecke that sulphur rather than phosphate was limiting, he replied that so far there was no such indication. To a question on magnesium levels, Gibbs said that analyses suggested that they could be regarded as adequate.

Asked whether clover loss could be caused by poor nodulation, Falloon agreed that it was poor and posed a big problem. He felt high acidity could have an important bearing, and he thought it would probably pay to oversow some areas again with prilled and inoculated seed, He had only recently used lotus, but had found subterranean clover to be a very useful pioneer plant which would enable fertility to be built up in many areas to the stage where white clover could perhaps be used more successfully. 